\title{
OBLIGATORY COMMISSIONS AND CONSULTATIVE BODIES IN LEGISLATIVE BODIES OF TERRITORIAL SELF-GOVERNMENT UNITS IN POLAND AND TERRITORIAL COMMUNITIES IN FRANCE - DIRECTIONS OF CHANGES ${ }^{1}$
}

\author{
Monika Augustyniak*
}

\begin{abstract}
The value of consultative democracy can not be overestimated, especially considering the local and supra-local administration gradually bringing the resident closer to self-government communities. Therefore, this issue is important and still requires improvement in the area of mutual relations between self-government authorities and residents of communes, districts/departments, voivodeships/ regions. The search for common relations in participating in the management of the self-government community is a current challenge facing the territorial self-government in both legal orders.

The comparative perspective in the scope of the functioning of commissions and consultative bodies of an obligatory nature is aimed at getting acquainted with the consultative administration in the territorial self-government in both legal orders and proposing directions of changes to Polish legal regulations in this area to improve the consultative dialogue and its normative tools.
\end{abstract}

${ }^{1}$ Research project carried out at the Faculty of Law, Administration and International Relations at Andrzej Frycz Modrzewski Krakow University financed from funds for statutory activities on the basis of the decision no. WPAiSM/DS/3/2016-KON.

* Prof. nadzw. dr hab. Monika Augustyniak, Associate Professor Andrzej Frycz Modrzewski Krakow University, Faculty of Law, Administration and International Relations at Andrzej Frycz Modrzewski Krakow University. 
Key words: consultative administration, obligatory commissions, consultative dialogue, deliberative democracy

\section{INTRODUCTION}

Local democracy may consist not only in bringing the administration closer to the public, but also in informing or improving the operation of consultative bodies. Such bodies include commissions functioning in the structure of legislative bodies of territorial self-government units in the Polish and French legal order, and other consultative bodies, especially those operating in the French territorial self-government. The active participation of commissions and consultative bodies in the work of the council/sejmik (local parliament) or the commune/department/regional council ensures proper performance of tasks of the bodies of territorial self-government units in Poland and territorial communities in the French Republic. They also facilitate communication between representatives of indirect democracy and residents of individual self-government communities. This special consultative dialogue is aimed at ensuring proper relations between the primary and secondary authority ${ }^{2}$ in the territorial self-government and proper and effective performance of tasks aimed at satisfying the needs of the self-government community. Both in the Polish and French legal orders one can distinguish obligatory and optional consultative commissions and bodies. The subject of interest of this article is to determine the legal basis, the subjective and objective scope of activities of consultative commissions and bodies of an obligatory nature in the structure of legislative bodies of territorial self-government units in both legal orders. All presented issues will become the basis for proposing directions of changes in the Polish legal order.

${ }^{2}$ A. Szewc indicates that the primary subject of authority are residents, and the secondary one are bodies of a given territorial self-government unit - see A. Szewc, in: A. Szewc, G. Jyż, Z. Pławecki (ed.), Ustawa o samorządzie gminnym. Komentarz [Act on commune self-government. Commentary], (ed.) 3, Warsaw 2010, p. 150) et seq. 


\section{INTERNAL COMMISSIONS OF AN OBLIGATORY NATURE IN LEGISLA-}

TIVE BODIES OF TERRITORIAL SELF- GOVERNMENT UNITS IN POLAND AND TERRITORIAL COMMUNITIES IN FRANCE

In the French legal order, consultative commissions and bodies operating in the structure of territorial self-government are regulated on the basis of the provisions of the General Code of Territorial Communities $\left(\mathrm{CGCT}^{3}\right)$. The consultative administration is one of the specific features of the French administration ${ }^{4}$. It is characterized by a large number of various bodies and commissions, often of an obligatory nature, which are consulted by the authorities and decision-making bodies of the state administration. Their task is a consultative dialogue, ensuring the proper functioning of self-government administration.

There are thematic commissions functioning in the structure of legislative bodies, which are appointed on the basis of CGCT regulations and the internal regulations of the councils of communes/departments and regions. Depending on local social needs, the catalogue of these commissions may be different. As a rule, they are appointed for the term of office of legislative bodies of territorial communities' units, lasting 6 years in the French Republic 5 . This corresponds to the appointment of permanent commissions in the Polish legislative body, also established for the term of office, which in this case is 4 years. It should be emphasized that the term of the legislative bodies in the Polish legal order has been changed from 4 years to 5 years under the Act of 11 January 2018 on amending certain acts to increase the participation of citizens in the process of electing, operating and controlling certain public bodies ${ }^{6}$.

${ }^{3}$ Code général des collectivités territoriales (General Code of Territorial Communities, CGCT) - source: https://www.legifrance.gouv.fr.

${ }^{4}$ See M.-H. Bacqué, H. Rey, Y. Sintommer, La démocatie participative, un nouveau paradigme de l'action publique?, in: Gestion de proximité et démocratie participative. Une perspective comparative, -H. Bacqué, H. Rey, Y. Sintommer (ed.), Paris 2005, p. 16.

${ }^{5}$ See J. Morand-Deviller, Droit administratif, Paris 2015, p. 163.

${ }^{6}$ See the Act of 11 January 2018 on amending certain acts to increase the participation of citizens in the process of electing, operating and controlling certain public bodies (Journal of Laws, item 130). 
This provision will apply from the next term of the bodies of territorial selfgovernment units.

In the French legal system, an obligatory commission appointed in communes above 3500 inhabitants is a regulation commission, obliged to adopt the new council's internal regulations ${ }^{7}$ within six months of the new term of office of the legislative body. This commission is also appointed obligatorily at the beginning of the council's term in the department and in the region. The commission consists of councillors, on the basis of proportional representation in a given legislative body. The work of the commission is chaired by the mayor or his/her designated deputy, responsible for the organization and functioning of the meetings of the legislative body $^{8}$. In the Polish legal system, the statute of a territorial self-government unit is not an act providing for the term of office', therefore the legislator does not make it mandatory to appoint this commission, leaving this decision to councillors who at any time during the term may consider it necessary to modify the statute of a given territorial self-government unit $^{10}$. The obligatory character of the commune, district and voivodeship statute may be considered at the beginning of the term of the legislative bodies based on the model of French regulations. However, it should be noted, on the one hand, that term limits of the statute allow for the possibility of adapting local and regional statutes to the constantly changing statutory regulations in the Polish legal order and current needs of residents of self-government communities. On the other hand, this indicates

${ }^{7}$ Internal regulations may be subject to appeal to the administrative court - see M. Verpeaux, L. Janicot, Droit des collectivités territoriales, $3^{\text {e }}$ édition, Paris 2015, p. 280.

${ }^{8}$ See rules of procedure of the Council of Paris (source: https://www.paris.fr/municipalite/le-conseil-de-paris/fonctionnement-du-conseil-de-paris-216\#le-reglement-interieur_13, [date of access: 03.03.2018]. In the Council of Paris this commission consists of 12 councillors.

${ }^{9}$ See J. Korczak, Statuty jednostek samorządu terytorialnego i jednostek pomocniczych gmin [Statutes of territorial self-government units], in: Grancie samodzielności wspólnot samorządowych [Limits of independence of self-government communities], E. Ura (ed.), Rzeszów 2005, p. 137.

${ }^{10}$ It is worth noting that in the Polish territorial self-government, the statutory commission may be appointed as a permanent commission, operating throughout the term of office or an ad hoc commission (appointed ad hoc, until a specific modification of the statute). Both solutions are legally permissible and used in practice. 
a high degree of instability of the statute matter, which may cause concern to the addressees of this basic systemic-legal act in communes, districts and voivodeships. Despite these doubts, I agree with the solutions proposed by the French legislator, because these regulations meet more the current needs of residents of local communities and allow for efficient functioning of councillors in each new term, for whom statutory regulations may often facilitate work for the benefit of the territorial community.

Thematic commissions consist of councillors of a given territorial community. The number of their members should be specified in the matter of internal regulations or by way of a separate resolution of the council. For example, the Council of Paris has the Finance, Trade, Employment and Human Resources Commission, comprising 27 councillors. This commission has a wide subjective scope, because it deals with the issues of public finance, public markets, concessions, human resources, public services, modernization of administration, trade, craft, social and solidarity economy, social innovations and the circular economy and employment ${ }^{11}$. The composition of the commission is publicly known and subject to publication in the bulletin of a given territorial community. Each French councillor may participate in several thematic commissions, to which he/she is elected by virtue of a resolution of the council. Restrictions in this respect may appear in the internal regulations of a given council of the commune/ department or region. Typically, the commission consists of representatives of all clubs (groups of councillors). The tasks of the thematic commissions include the analysis of draft resolutions or their preparation for deliberations by the council. The commissions may submit amendments to draft resolutions (by majority of votes in the presence of councillors present at the commission meeting) and proposals and respond to written questions addressed to commissions covering their scope of activity. Thus, it should be stated that the subjective scope of commissions in both legal orders is, in principle, the same. These commissions are bodies that prepare materials for the deliberations of legislative bodies, contributing to the effectiveness of their work, often being the emanation of their com-

${ }^{11}$ See composition of commissions in the Council of Paris - source: https://www.paris.fr/municipalite/le-conseil-de-paris/fonctionnement-du-conseil-de-paris-216\#le-reglement-interieur_13, [date of access: 02.03.2018]. 
petences. In both legal orders, the role of the commissions is significant and plays an important role in the performance of basic tasks of territorial self-government units/territorial communities.

In the Polish legal order, a councillor may be elected to any commission, taking into account certain restrictions in this area provided for by the legislator for the audit commission in the commune/district council or voivodeship sejmik. The legislator in art. 18 a par. 2 of the Act of 8 March 1990 on commune self-government ${ }^{12}$, in art. 16 par. 2 of the Act of 5 June 1998 on district self-government ${ }^{13}$ and in art. 30 par. 2 of the Act of 5 June 1998 on voivodeship self-government ${ }^{14}$ introduces a provision that the audit commission consists of councillors, including representatives of all clubs ${ }^{15}$, with the exception of councillors acting as chairperson and deputies of the council or sejmik and councillors who are members of the governing board in the district and voivodeship (including the voivodeship marshal). This means that the quantitative composition of the audit commission depends on the discretion of the council/sejmik, but it can not be different from the one regulated in the statute, and in this commission the number of members must be shaped in such a way that each club is represented by at least one councillor ${ }^{16}$. In the judgement of 19 July 2012 the Voivodeship Administrative Court in Lublin stated that: "According to art. 18a par. 2 of the Act on commune self-government the audit commission consists of councillors, including representatives of all clubs According to the above-mentioned provision, non-attached council members may also be part of the commission, nevertheless clubs have undoubtedly a privileged

${ }^{12}$ See the Act of 8 March 1990 on commune self-government (consolidated text Journal of Laws of 2017 item 1875 as amended.) - hereinafter referred to as ACSG.

${ }^{13}$ See the Act of 5 June 1998 on district self-government (consolidated text Journal of Laws of 2017 item 1868 as amended.) - hereinafter referred to as ADSG.

${ }^{14}$ See the Act of 5 June 1998 on voivodeship self-government (consolidated text Journal of Laws of 2017 item 2096 as amended.) - hereinafter referred to as AVSG.

15 The provisions of the systemic self-government acts introduce regulations, according to which councillors in legislative units of communes, districts and voivodeships can create council clubs acting on the principles specified in the statute of a given commune, district or voivodeship respectively.

${ }^{16}$ See judgement of the Voivodeship Administrative Court in Gorzów Wielkopolski of 6 October 2016, II SA/Go 705/16, LEX no. 2151022. 
position in shaping the composition of the audit commission" ${ }^{17}$. In the judgement of the Voivodeship Administrative Court in Olsztyn of 29 May 2017 it was pointed out that "the quantitative limitation of the composition of the council commission, determined by resolution of the council, does not violate the law, if it does not directly hinder the commune's bodies to perform public tasks, nor does it exclude councillors, as representatives of the commune, from participating in the works of the commune council and its bodies appropriately to their obligation referred to in art. 24 of the Act on commune self-government. Thus, the commune council, selecting the composition of permanent commissions, should, bearing in mind the principles of democratic deliberation and voting, ensure that councillors have fairly equal working conditions in council commissions. Incontestably, the councillor also has the right, and not the obligation to be a member of any number of commune council commissions, but this right can not be limited by shaping the quantitative composition of commission members in a way that precludes the possibility of participating in any commission" 18 .

The participation of residents in the work of thematic commissions in the French legal order is excluded, as these commissions operate in camera $^{19}$. These regulations can be found in the matter of the internal regulations of each legislative body at the level of the commune/department and region. In the Polish legal order, the commissions' activity is public, ergo residents have access to their meetings (external disclosure) and to the documentation of each commission (internal disclosure ${ }^{20}$ ). This applies to both permanent commissions (e.g. finance commission), ad hoc commissions (e.g. commission for controlling the performance of a given

${ }^{17}$ See judgement of 19 July 2012 of the Voivodeship Administrative Court in Lublin, III SA/Lu 259/12, LEX no. 1217256.

${ }^{18}$ See judgement of the Voivodeship Administrative Court in Olsztyn of 29 May 2017 (II SA/Ol 300/17, LEX no. 2305068).

${ }^{19}$ See internal regulations of the Council of Paris (source: https://www.paris.fr/municipalite/le-conseil-de-paris/fonctionnement-du-conseil-de-paris-216\#le-reglement-interieur_13, [date of access :04.03.2018].

${ }^{20}$ On internal and external disclosure see P. Sitniewski, Dostęp do informacji publicznej w jednostkach samorządu terytorialnego [Access to public information in territorial self-government units], Białystok 2005, p. 57 et seq. 
task by the executive body), optional (e.g. commissions for amending the commune's statute) or obligatory ones (e.g. audit commission). The size of a given commission depends on regulations included in the statute. Although it is the right and at the same time duty of the councillor to participate in the work of the commission of the legislative body, the councillor can not usurp membership in a specific commission, for example a spatial planning commission. This view is reflected in jurisprudence of administrative courts. In its judgement of 9 March 2004 the Voivodeship Administrative Court in Kraków stated that "The statutory right of the councillor to participate in the work of the commission does not mean either the councillor's claim for election to the commission he or she would prefer, or the right to membership in an unlimited number of commissions. The statute should include all allowed rules rationalizing team work of councillors, and such elementary rules must include determining the maximum number of commissions in which councillors are required to participate" 21 . Pursuant to art. 24 ACSG. "the councillor is obliged to take part in the works of the commune council and its commissions as well as other self-government institutions to which he/she has been elected or appointed". We find similar legal regulations in the Act on district self-government and voivodeship self-government (see art. 21 ADSG and art. 23 AVSG). In the judgement of 3 November 2016 the Voivodship Administrative Court in Łódź stated that "in a situation when the councillor disorganizes the sejmik's proceedings and does not comply with the adopted agenda and rules of procedure of sejmik, the councillor's exclusion from the meeting by the chairperson does not violate art. 23 par. 3 AVSG, because the councillor actually does not perform his/her duties"22. This means that the right and also the obligation of the councillor to participate in the work of the body ${ }^{23}$ and its internal commissions or organizational units is however subject to limitations.

${ }^{21}$ See judgement of 9 March 2004 of the Voivodeship Administrative Court in Kraków (II SA/Kr 3167/03, LEX no. 722061).

22 See judgement of the Voivodeship Administrative Court in Łódź of 3 November 2016 (III SA/Łd 630/16, LEX no. 2155014).

${ }^{23}$ More on the legal status of a councillor, see comments made by R. Marchaj, in: B. Dolnicki (ed.) Local goverment in Poland and Portugal, Warsaw 2015, p.72 et seq. 
In the French legal order, the scope of activity as well as the composition of the commission is determined by a separate resolution of the legislative body, although the list of commissions can already be adopted in the provisions of the internal regulations of a specific council, which is limited by term (differently from the Polish legal order). For example, in the Grand-EST Regional Council there are 15 thematic commissions, e.g. finance commission, youth commission, spatial planning commission, agriculture and forestry commission, vocational training commission, commission for higher education and research, commission for environmental protection, tourism, sport ${ }^{24}$. In the sejmik of the Lesser Poland (Małopolskie) Voivodeship there are permanent commissions (ten) with a very similar scope of activity to the commissions mentioned above, e.g. budget, property and finance commission, environmental protection and public safety commission, commission for innovation and modern technologies, commission for agriculture and modernization of rural $\operatorname{areas}^{25}$. In addition to the permanent commissions mentioned above, ad hoc commissions, appointed ad hoc, can also be set up in the council/sejmik to settle a specific case ${ }^{26}$. In genere, it should be stated that in the Polish legal order, commissions perform an auxiliary function for the legislative body of the commune, district, voivodeship and can not take over the powers of the council/sejmik, ergo do not constitute law (they do not have the competence to issue local law acts ${ }^{27}$ ) and do not act pro foro externo. The

${ }^{24}$ See list of thematic commissions in the Grand EST Regional Council (source: https://www.grandest.fr/le-conseil-regional, [date of access: 04.03.2018].

${ }^{25}$ See list of thematic commissions in the Grand EST Regional Council (source: https://www.grandest.fr/le-conseil-regional, [date of access: 04.03.2018].

see. e.g Chapter VI of the Statute of the Lesser Poland Voivodeship (Resolution no. XII/183/15 of the Sejmik of the Lesser Poland Voivodeship of 31 August 2015 regarding the publication of a uniform text of the Statute of the Lesser Poland Voivodeship source: ttps://bip.malopolska.pl/umwm,m,2837,statut-wojewodztwa.html, [date of access 05.03.2018].

${ }^{26}$ See information on ad hoc commissions in the Lower Silesia Voivodeship sejmik http://www.umwd.dolnyslask.pl/sejmik/sejmik-i-jego-organy/komisje-sejmiku/, [date of access: 05.03.2018].

${ }^{27}$ E.C. Malisz emphasizes that "one of the basic features of local law is limiting its operation to the area on which the authority authorized to issue local law acts" - E.C. Malisz, Samorządowe prawo miejscowe [Local government law], Zielona Góra 2001, p. 
commissions do not replace the legislative body, as auxiliary bodies they help carry out tasks of the commune council, in particular by issuing opinions on draft resolutions of the council/sejmik, formulating motions to commune bodies and preparing draft resolutions. It should be emphasized that the resolution is a typical form of expressing opinions of the commissions as collegial bodies with no legislative competences. As pointed out by A. Wierzbica, "the resolution of a collegial body is undoubtedly a decision which is an act of will of each member of this body who, by voting, expresses his/her position on the matter put to vote" 28 .

The legislative body in territorial self-government units selects the personal composition of a given commission from among candidates proposed by clubs and non-affiliated councillors, or at the request of other entities having the right of legislative initiative, e.g. chairman or deputy chairperson of the council/sejmik. The chairperson of the commission and his/her deputies are elected by the council/sejmik. The chairperson of the commission is responsible for conducting its deliberations and directing its work, in particular: preparing draft work plans of the commission, setting dates and agenda of the meeting, ensuring that commission members receive in due time duly prepared materials and representing the commission within the structure of a given territorial self-government unit. The chairperson of the commission elaborates the draft annual commission work plan and determines the agenda of its meeting, taking into account the requests of the bodies of the territorial self-government unit.

In the French legal system, an obligatory commission appointed at the beginning of the term of office of the legislative bodies in the department and region is the permanent commission (commission permanente), regulated pursuant to the provisions of CGCT (see. art. L3122-4 CGCT and art. L4133-4 CGCT). It does not appear in the structure of the French commune. The permanent commission should be appointed at the beginning of the term of office of the departmental and regional council. Its pur-

20. On types of local law acts see D. Dolnicki, Samorząd Terytorialny [Territorial self-government], Warsaw 2016.

${ }^{28}$ See. A. Wierzbica, Referendum i wybory oraz zarządzenia i uchwały jednostek samorządu terytorialnego [Referendum and elections and ordinances and resolutions of territorial self-government units], Warsaw 2014, p. 336. 
pose is to ensure continuation of the work of the legislative body between sessions of the departmental regional council. The legislative body may entrust the commission with its specific tasks and competences, thereby it becomes the emanation of its powers. Resolutions of the permanent commission are adopted by a majority of votes cast. The role and function of this commission are regulated in the CGCT regulations. The departmental and regional council at the beginning of its deliberations elects the chairperson of the council, who ex lege is a member of the commission and his/her deputies (from 4 to 15 council deputy chairpersons with the reservation that their number does not exceed $30 \%$ of council members in this commission) and other members. Members of the permanent commission (this does not apply to the chairperson) are elected in a vote from lists of candidates of both sexes, proposed by the councillors of the department ${ }^{29}$ or region, respectively. Subsequently, the permanent commission adopts resolutions within its scope of its competences ${ }^{30}$. It should be emphasized that there is a statutory ban on transferring to the permanent commission matters within the scope of budget issues, approval of the administrative account and compulsory expenditure. The prohibition on sub-delegation in question results from the provision of art. L3211-2 CGCT and art. L. 4221-5 CGCT. Members of the permanent commission are elected for the term of office of the chairperson of the council.

It is worth noting that the meetings of the permanent commission are not public, although the sessions of the departmental and regional council are generally available to residents of the self-government community. The permanent commission, under the supervision of the chairperson of the council as the executive body, is a body that replaces the legislative body, hence the role of this commission is significant. The commission's competences also include the possibility of requesting the convening of a plenary

${ }^{29}$ See article L3122-5 CGCT.

${ }^{30}$ P. Leprêtre, Les collectivites territoriales, Paris 2016, p. 51. See the composition of the permanent commission in the Region of Normandy, https://www.normandie.fr/la-commission-permanente, [date of access: 03.03.2018]. Whereas the permanent commission in the Bretagne Region consists of 27 regional councillors. This commission meets once a month to implement decisions taken at the plenary session by the regional council source: http://www.bretagne.bzh/jcms/preprod_94985/fr/les-commissions-permanentes2017, [date of access: 03.03.2018]. 
meeting of the departmental/regional council. The permanent commission is the body that is supposed to speed up the work of the legislative body, hence restriction of the transparency of its meetings. The doctrine of French administrative law emphasizes the important role of this commission, pointing to its practical function, unfortunately often underestimated by the authorities ${ }^{31}$. It should be noted that in the Polish legal order there is no such body functioning in the structure of bodies at the level of a district and voivodeship. I think that the introduction of the permanent commission should be considered, which could replace the legislative body in terms of its issues delegated to it. Certainly, this would improve the work of bodies and strengthen their mutual relations (personal and functional). However, this change requires modification of statutory provisions in the Polish territorial self-government.

A certain novelty in the Polish legal system is the introduction, pursuant to the Act of 11 January 2018 amending certain acts to increase the participation of citizens in the process of electing, operating and controlling certain public bodies ${ }^{32}$, of an obligatory commission for complaints, petitions and requests, appointed within the legislative body of a given territorial self-government unit. This commission is tasked with examining complaints about the activities of the executive body and self-government organizational units of a given unit as well as requests and petitions submitted by citizens. This commission includes only councillors, including representatives of all clubs. Membership in the commission for complaints, requests and petitions can not be combined with the functions of the voivodeship marshal, chairperson and deputy chairpersons of the council/sejmik and councillors who are members of the district/ voivodeship board. The rules and mode of operation of this commission are determined by the statute of a given territorial self-government unit. So far, these functions were performed by an audit commission, appointed in each territorial self-government unit as an obligatory commission. It

${ }^{31}$ See also M. Verpeaux, L. Janicot, Droit des collectivités territoriales, $3^{\mathrm{e}}$ édition, Paris 2015 , p. 283.

32 See the Act of 11 January 2018 on amending certain acts to increase the participation of citizens in the process of electing, operating and controlling certain public bodies (Journal of Laws, item 130). 
should be noted that there is no such thematic commission in the French legal order appointed under the provisions of CGCT.

\section{OTHER CONSULTATIVE BODIES}

OF AN OBLIGATORY NATURE ESTABLISHED IN LEGISLATIVE BODIES

OF TERRITORIAL COMMUNITIES

In the French legal system, an essential commission of an obligatory nature is the Consultative Commission on Local Public Services (Commission consultative des services publics locaux) which in accordance with art. L. 1413-1 CGCT, is set up in all territorial communities ${ }^{33}$ in the French Republic. This commission is established for all public services transferred to an external entity or provided by a financially independent municipal plant. Its aim is to enable residents or users of services through local associations to submit advice or opinions. This commission is chaired by the executive body of the territorial community and is composed of members of the legislative body on the basis of proportional representation, representatives of local associations appointed by the council of the commune/ department/region ${ }^{34}$. In addition, the commission may invite other people whose participation it deems necessary, including residents, to participate in its work. This formula is flexible and is a kind of courtesy to the residents, direct democracy. The tasks of this commission include the annual examination of reports that must be submitted by entities implementing public service obligations, such as reports on prices and quality of drinking water, treatment of municipal waste ${ }^{35}$. This commission also acts as a consultative body for a legislative body in a given territorial community. It was also equipped by the French legislator with the right of a legislative initiative, because the majority of commission members may request to

${ }^{33}$ This applies to communes with more than 10,000 inhabitants - see J. Waline, Droit administratif, Paris 2016, p. 142.

${ }^{34}$ See M. Verpeaux, Ch. Rimbault, F. Waserman, Les collectivités territoriales et la décentralisation, Paris 2016, p. 85.

${ }^{35}$ See article L. 1414-14 CGCT. 
include in the agenda of the meeting of the territorial community council proposals to improve local public services. In the Polish legal order, the legislator does not provide for such a commission, although it seems right to call for its appointment. The aim of this commission is continuous improvement of public services, which certainly ensures greater transparency in the management of these services ${ }^{36}$ (this concerns both the quality of services, including their prices) and better serves to meet the needs of local residents. De lege lata in the Polish legal order permanent commissions of an internal nature are appointed, which deal with the issues such as infrastructure and transport. It should be emphasized, however, that they are not alternatives to the Consultative Commission on Local Public Servicesbecause they do not correspond to either its subjective scope (because in Poland they are composed only of councillors of a given unit, and in France this composition is extended to external entities, including residents), or objective scope (commissions in the Polish legal order do not examine reports of entities implementing public service obligations and they do not issue any binding decisions in this respect, unlike in France). Thus, the introduction of the body in question is postulated within the structure of bodies of territorial self-government units in the Polish legal order.

It is worth noting that each department has a Departmental Commission for Inter-communal Cooperation (Commission départementale de la coopération intercommunale) on the basis of provisions of CGCT (see. art. L. 5211-42 CGCT et seq.). It is headed by a prefect and a prefecture fulfils the function of a secretariat. The Commission consists of at least 40 members. This number may increase depending on the number of residents, the number of communes and the number of communes above 100,000 residents $^{37}$. The commission's meetings are open to the public except in situations where the majority of the members present and represented decide to keep the deliberations secret. Departmental Commission for Inter-communal Cooperation draws up and updates a report on intercommunal cooperation in the department. The commission's tasks include

\footnotetext{
${ }^{36}$ See M. Thoumelou, Collectivités territoriales, Quel avenir?, Paris 2016. p. 131 et seq.

${ }^{37}$ See J. Ferstenbert, F. Priet, P. Quilichini, Droit des collectivités territoriales, Paris 2016, p. 282.
} 
formulating any proposals to strengthen inter-communal cooperation. The prefect consults with the commission each project to create a public inter-communal cooperation unit (EPCI). Each communes' association's project is forwarded to the commission to develop an inter-communal spatial management and development charter (charte intercommunale de développement et d'aménagement). The commission's proposals and remarks are made available to residents ${ }^{38}$.

There is no such commission or its equivalent in the Polish legal system. It is necessary to consider the possible need for its introduction and regulation in self-government acts, especially at the district level due to the important role of inter-communal cooperation. Strengthening cooperation between communes would bring many benefits, for example in the field of service provision.

Whereas in the region the French legislature provided for the establishment of the Regional Economic, Social and Environmental Council (Conseil économique, social et environnemental régional), which acts as the main consultative body of an obligatory nature at the level of the metropolitan region. This council operates at the regional council and its chairperson $^{39}$. Council members are divided into four colleges ${ }^{40}$ (see. art. R. 4134-1 CGCT):

- representatives of enterprises and entities conducting activity on their own in a given region;

- representatives of trade union organizations representative at the central level;

- representatives of bodies and associations taking part in the social life of the region;

- persons who due to their merits or activities contribute to the development of the region.

All members of the Regional Economic and Social Council are appointed for a period of 6 years and may not be deprived of electoral rights.

${ }^{38}$ See decision of the Council of State of 29 March 2000, Minister of Internal Affairs/ Maillet, no. 203975.

${ }^{39}$ See article L. 4234-1 CGCT.

${ }^{40}$ See article L. 4134-1 CGCT. 
The Regional Economic, Social and Environmental Council elects from among its members a chairperson and an office (whose composition is determined by the council's regulations) for a period of three years with the possibility of re-election ${ }^{41}$. The Council may appoint commissions as well as specialized and temporary working groups to carry out its tasks. The Economic, Social and Environmental Council issues opinions on documents related to the preparation and implementation in the region of a national plan ${ }^{42}$, draft regional plan and annual stocktaking of its implementation, individual budget documents of the region, general directions in areas the Regional Council is considering, deliberating on matters falling within in its competences. The chairperson of the Regional Council may submit to the Council motions for opinion and analysis in all matters of economic, social and environmental nature. In addition, he/she may issue opinions on matters falling within the competence of the region ${ }^{43}$.

The body does not find its equivalent in the Polish legal order. This council is an interesting model, worth the appropriate transfer to Polish legal regulations.

\section{DIRECTIONS OF CHANGES}

In Polish and French territorial self-government, the legislator and the local legislator decided to establish a wide range of commissions and other consultative bodies of an obligatory nature (with a stronger emphasis on French regulations in this area) operating within the organizational structure of legislative bodies of communes, districts/departments and voivodeships/regions). These bodies have the task of not only facilitating the proper preparation of legislative bodies to make right decisions, taken after an earlier analysis by relevant thematic commissions but they also provide for the participation of the local community inhabitants in making decisions or their participation in the consultation processes in the field of activity

\footnotetext{
${ }^{41}$ See B. Faure, Droit des collectivités territoriales, Paris 2014, p. 154 et seq.

42 See article L. 4241-1 CGCT.

${ }^{43}$ See M. Thoumelou, Collectivités territoriales, Quel avenir?, Paris 2016. p. 104.
} 
of a given authority. Analysing draft resolutions and presenting them and expressing opinions and positions by obligatory commissions in relation to actions taken by legislative bodies of territorial self-government should be considered the right direction of indirect democracy in both legal orders, which univocally approaches participatory democracy, allowing participation of citizens in management of the self-government community.

Permanent Commission (commission permanentne), which replaces the legislative body in the department and region in the French legal order, in key matters concerning the functioning of the legislative bodies, de facto does not deprive them of decisions on matters most important to the council of these territorial communities (i.e., budgetary and financial matters) . It streamlines the work of legislative bodies, ensuring continuity of decisions and meeting the current needs of residents of supra-local and regional self-government in the French Republic. Therefore, the transfer of these legal solutions to Polish systemic self-government laws at the district and voivodeship level seems to be desirable.

The Polish legal order providers for appointment of permanent internal commissions which do not correspond to the subjective and objective scope of the Consultative Commission on Local Public Services. In would be advisable to introduce to the structure of territorial self-government units, on the example of the French consultative solutions, an obligatory commission which would analyse reports of entities implementing public service obligations and issue not only opinions and formulate conclusions in this respect, but first of all present a binding position for bodies of units to take relevant decisions to continue or terminate a contract with a specific public service provider or improve the quality of the services offered. This commission should enable public service users to actively participate in the preparation of decisions taken as part of the management of local public services, which reflects good relations between representatives of direct and indirect democracy. Only such relations give both sides of this social dialogue a guarantee of satisfaction in self-governing a territorial community.

In the French legal order, pursuant to CGCT provisions, each department has a Departmental Commission for Inter-communal Cooperation, which not only draws up and updates a report on inter-communal cooperation in the department, but also undertakes actions to strengthen this 
cooperation. In the Polish legal order, the legislator did not envisage such a body under the Act. One should consider the possible need for a similar commission and its regulation in self-government acts, especially at the district level due to the important role of inter-communal cooperation which could serve to develop coherent development strategies for functional areas, taking into account the needs of individual communes, while limiting competition between them.

Moreover, in the Polish legal order there is no Regional Economic, Social and Environmental Council which functions as an obligatory consultative body at the regional level in the French Republic. However, it is worth considering the introduction of this consultative structure to Polish regulations at the voivodeship level due to the role and function that this Council fulfils. All the remarks made above regarding the commissions and consultative bodies lead to the conclusion that it is difficult to underestimate this important consultative structure of the French administration, which may become a model for Polish systemic solutions.

\section{REFERENCES}

Bacqué M. H., Rey H., Sintommer Y. 2005, La démocatie participative, un nouveau paradigme de l'action publique?, in: Gestion de proximité et démocratie participative. Une perspective comparative, -H. Bacqué, H. Rey, Y. Sintommer (ed.), Paris.

Dolnicki Bogdan. 2016, Samorząd Terytorialny [Territorial self-government], Warsaw.

Ferstenbert J., Priet F., Quilichini P. 2016, Droit des collectivités territoriales, Paris.

Korczak Janusz. 2005, Statuty jednostek samorządu terytorialnego i jednostek pomocniczych gmin [Statutes of territorial self-government units], in: Grancie samodzielności wspólnot samorządowych [Limits of independence of self-government communities], E. Ura (ed.), Rzeszów.

Malisz E. C. 2001, Samorządowe prawo miejscowe [Local government law], Zielona Góra.

Marchaj R. 2015, in: B. Dolnicki (ed.), Local goverment in Poland and Portugal, Warsaw. 
Morand-Deviller J. 2015, Droit administratif, Paris.

Sitniewski Piotr. 2005, Dostęp do informacji publicznej w jednostkach samorzą$\mathrm{du}$ terytorialnego [Access to public information in territorial self-government units], Białystok.

Szewc Andrzej. 2010, in: A. Szewc, G. Jyż, Z. Pławecki (ed.), Ustawa o samorządzie gminnym. Komentarz [Act on commune self-government. Commentary], ed. 3, Warsaw.

Thoumelou M. 2016, Collectivités territoriales, Quel avenir?, Paris.

Verpeaux M., Janicot L. 2015, Droit des collectivités territoriales, $3^{e}$ édition, Paris. Wierzbica A. 2014, Referendum i wybory oraz zarządzenia i uchwały jednostek samorządu terytorialnego [Referendum and elections and ordinances and resolutions of territorial self-government units], Warsaw. 
